\title{
Persistent complete molecular remission after nilotinib and graft-versus-leukemia effect in an acute lymphoblastic leukemia patient with cytogenetic relapse after allogeneic stem cell transplantation
}

\author{
Paul Farnsworth, David Ward and Vijay Reddy*
}

\begin{abstract}
We report the successful treatment and sustained molecular remission using single agent nilotinib in a relapsed Philadelphia chromosome positive $(\mathrm{Ph}+)$ acute lymphoblastic leukemia patient after allogeneic hematopoietic stem cell transplantation. Compared to previously published studies, this is the first report where a patient did not receive additional chemotherapy after relapse, nor did she receive donor lymphocyte infusions. With nilotinib, the patient reverted back to normal blood counts and $100 \%$ donor reconstitution by single tandem repeat (STR) chimerism analysis in the bone marrow and in peripheral blood, granulocytes, T and B-lymphocytes. This report also highlights the use of nilotinib in combination with extracorporeal photopheresis (ECP) for concomitant graft-versus-host disease. Our data suggests that ECP, together with nilotinib, did not adversely affect the overall Graft-versus-leukemia (GVL) effect.
\end{abstract}

Keywords: Philadelphia chromosome positive acute lymphoblastic leukemia (PH + ALL), Nilotinib, Extracorporeal photopheresis (ECP), Graft-versus-host disease (GVHD), Graft-versus-leukemia effect (GVL), Hematopoietic stem cell transplantation (HSCT)

\section{Background}

Philadelphia chromosome $(\mathrm{Ph}+)$ is the most common cytogenetic abnormality in adult ALL and is the translocation between chromosome 9 and 22 demonstrating BCR-ABL gene rearrangement and accounts for approximately $20-30 \%$ of all adult ALL cases [1]. It carries an adverse prognosis with standard chemotherapy alone, requiring allogeneic bone marrow transplant for a curative approach. First and second generation TKI's were developed to target the BCR-ABL fusion protein [2]. The availability of these new agents is changing the treatment paradigm and the prognosis for these patients. Using imatinib as a single agent showed short-lived responses to treatment, and thus new studies were done using imatinib with concomitant chemotherapy. One such study

\footnotetext{
* Correspondence: vreddymedicine@gmail.com

Florida Hospital Cancer Institute, University of Central Florida, 2501 N. Orange Avenue. Suite 581, Orlando, FL 32804, USA
}

showed $96 \%$ of patients achieving complete remission after a median of 21 days [3]. Second generation TKI's have significantly more potent antileukemia activity against BCR-ABL positive leukemia's and are under active investigation for ALL [4]. They have also shown great activity in patients with imatinib resistant $\mathrm{Ph}+$ ALL. Nilotinib is approximately 30 fold more potent than imatinib and is active in vitro against 32 of 33 BCR/ABL mutations [5]. A phase II study of nilotinib (400 mg twice a day) in relapsed or refractory Ph + ALL reported that $24 \%$ of patients attained a complete hematologic response (CHR) [6].

The utility of second generation TKIs as monotherapy in relapsed disease has not yet been fully evaluated [6,7]. We report the successful use of nilotinib as a single agent treatment in obtaining molecular remission for over one year in Ph + ALL that relapsed after allogeneic SCT. This patient reverted back to full donor reconstitution, leading 
to development of chronic graft-versus-host disease (GVHD). Despite additional immunosuppression and extracorporeal photopheresis (ECP), graft-versus-leukemia (GVL) effect was sustained and the patient remains in molecular remission.

\section{Case presentation}

A 54- year-old woman presented with Philadelphia chromosome-positive precursor B-cell acute lymphoblastic leukemia in March 2009. She received induction chemotherapy consisting of six cycles of Hyper-CVAD chemotherapy regimen. She also received imatinib along with the Hyper-CVAD regimen. A bone marrow biopsy was performed after the sixth cycle, which revealed complete remission (CR). Her central nervous system was negative for disease. The patient then underwent an allogeneic peripheral blood stem cell (PBSC) transplant in November 2009 from her brother who was a 6/6 HLA match with a CD34 cell dose of $7.5 \times 10^{6} / \mathrm{kg}$. Our patient was positive for CMV and the donor was CMV negative. The imatinib was stopped three days before her conditioning regimen started. She underwent a reduced intensity-conditioning regimen because of her age and co-morbid conditions, which consisted of hypertension, depression, anxiety disorder, and back pain related to multiple thoracolumbar vertebral compression fractures, due to leukemia, treated with kyphoplasty. The reduced intensity regimen consisted of flubarabine $\left(150 \mathrm{mg} / \mathrm{m}^{2}\right)$ and melphalan $\left(140 \mathrm{mg} / \mathrm{m}^{2}\right)$. GVHD prophylaxis consisted of FK 506 (Tacrolimus, Prograf) and methotrexate. A bone marrow biopsy done on day 30 showed complete molecular remission with 100\% male donor chimerism. However, our patient struggled from ongoing GVHD post-transplant. She developed acute GVHD six weeks after transplant involving the gut stage IV, skin stage III, and liver stage II with an overall acute GVHD of grade IV D. She was treated with high dose corticosteroids ( $2 \mathrm{mg}$ per $\mathrm{kg}$ ) but became steroid refractory, requiring the addition of CellCept, rituximab, Entocort, and Rapamune. She responded to this treatment and her immunosuppression was weaned down to $10 \mathrm{mg}$ of Prednisone daily along with cyclosporine. She was in complete molecular remission based RT-PCR and was $100 \%$ donor chimerism by single tandem repeat testing for Granulocytes, T-Lymphocytes and BLymphocytes and had male XY chromosome cytogenetics in the bone marrow. Eight months after transplant, due to her persistent need for immunosuppression due to her GVHD, she was started on imatinib but at a low dose of $50 \mathrm{mg}$ daily because of thrombocytopenia. Nine months after transplant she was diagnosed with Chronic GVHD involving the mouth, eyes, and skin with increased skin thickening and scleroderma of the lower back and thighs.
One year after HSCT, a bone marrow biopsy was negative for any residual leukemia by both flow cytometry and morphology. Cytogenetics was also normal. However, quantative RT PCR analysis of BCR/ABL gene arrangements for 9; 22 translation showed a positive minor breakpoint of $0.014 \%$. Upon seeing these results, her imatinib was increased from $50 \mathrm{mg}$ to $100 \mathrm{mg}$ daily. She could not tolerate a greater dose of imatinib due to her low platelet count. A subsequent bone marrow biopsy performed in December 2010 showed recurrent acute precursor B-Lymphoblastic leukemia compromising $71 \%$ of total cells. Cytogenic analysis also showed that 4 cells of 20 analyzed were female karyotype with deletion 3 and translocation 9; 22. This was new as her previous chromosome analyses following transplant have shown all twenty metaphase cells having a normal karyotype consistent with the donor hematopoiesis and no BCR/ABL cytogenetic translocation was detected in any of the samples. Chimerism studies showed $12 \%$ male donor cells, while peripheral blood still remained at $100 \%$ donor in granulocytes and T-lymphocytes and Blymphocytes. In light of this new evidence, the patient expressed her wishes not to undergo aggressive reinduction chemotherapy regimen followed by additional donor lymphocyte infusions. Due to this relapse, in January 2011, fourteen months after her transplant, imatinib was discontinued and nilotinib was started at a dose of $800 \mathrm{mg}$ daily (400 mg p.o.b.i.d.). In February 2011, another biopsy was performed and the morphology by flow cytometry was much improved, but residual acute lymphoblastic leukemia was detected, with approximately 4.4\% CD34+ TDT + blasts. A subsequent bone marrow analysis performed two months later in April 2011 showed no evidence of residual disease with RTPCR being negative. Clinical course for the patient is shown in Table 1.

Her GVHD symptoms continued to worsen after achieving 100\% donor engraftment for the second time, and she developed sub-mandibular swelling with acute parotitis. She was then treated with high dose corticosteroids $(1 \mathrm{mg} / \mathrm{kg})$. In order to reduce steroid toxicity the patient received ECP treatments starting in June 2011 and ending in September 2011, which led to a great improvement of her GVHD symptoms. In August she completed her seventh cycle of ECP treatment, and she stated a great improvement of her mouth and eyesight; she also continued on prednisone $15 \mathrm{mg}$ and cyclosporine $150 \mathrm{mg}$ p.o.b.i.d. However, in September she developed proximal muscle weakness as a form of steroid myopathy. Her steroids were weaned, and CellCept was added because of steroid intolerance. In October, she developed acute renal failure with a creatinine level around 6, and the cyclosporine was stopped as a result. Another biopsy performed in October 2011 showed no 
Table 1 Clinical Course of Patient

\begin{tabular}{|c|c|c|c|c|c|c|c|c|}
\hline $\begin{array}{l}\text { Dates (Time } \\
\text { from } \\
\text { transplant) }\end{array}$ & $\begin{array}{l}\text { March } 2009 \\
\text { At Diagnosis }\end{array}$ & $\begin{array}{l}\text { February } 2010 \\
\text { (Day 100) }\end{array}$ & $\begin{array}{l}\text { September } \\
2010(10 \\
\text { Months) }\end{array}$ & $\begin{array}{l}\text { October } \\
2010(11 \\
\text { Months) }\end{array}$ & $\begin{array}{l}\text { December } 2010 \\
\text {-January } 2011 \text { (14 } \\
\text { Months) }\end{array}$ & $\begin{array}{l}\text { February } \\
2011(15 \\
\text { Months) }\end{array}$ & $\begin{array}{l}\text { April } 2011 \\
\text { (17 Months) }\end{array}$ & $\begin{array}{l}\text { June 2011- } \\
\text { October } \\
2011(19-24 \\
\text { Months) }\end{array}$ \\
\hline $\begin{array}{l}\text { Bone } \\
\text { Marrow } \\
\text { Biopsy } \\
\text { Morphology }\end{array}$ & $\begin{array}{l}\text { Hypercellular } \\
90 \% \text { with } 56 \% \\
\text { B- } \\
\text { Lymphoblasts }\end{array}$ & $\begin{array}{l}\text { No evidence of } \\
\text { disease }\end{array}$ & Not done & $\begin{array}{l}\text { No } \\
\text { evidence } \\
\text { of disease }\end{array}$ & $\begin{array}{l}\text { Recurrent disease } \\
\text { comprising } 71 \% \text { of total } \\
\text { cells }\end{array}$ & $\begin{array}{l}\text { Residual } \\
\text { disease } 4.4 \% \\
\text { CD34+ } \\
\text { TDT + Blasts }\end{array}$ & $\begin{array}{l}\text { No evidence } \\
\text { of residual/ } \\
\text { recurrent } \\
\text { disease }\end{array}$ & $\begin{array}{l}\text { No evidence } \\
\text { of residual/ } \\
\text { recurrent } \\
\text { disease }\end{array}$ \\
\hline $\begin{array}{l}\text { Donor } \\
\text { Chimerism } \\
\text { BM/PB }\end{array}$ & $\begin{array}{l}\text { N/A Female } \\
\text { recipient }\end{array}$ & $\begin{array}{l}\text { 100\% male } \\
\text { donor by } \\
\text { chromosomes } \\
\text { and STR (BM) }\end{array}$ & Not done & $\begin{array}{l}100 \% \text { male } \\
\text { donor }\end{array}$ & $12 \%$ male donor & $\begin{array}{l}100 \% \text { male } \\
\text { donor }\end{array}$ & Not done & $\begin{array}{l}100 \% \text { male } \\
\text { donor }\end{array}$ \\
\hline $\begin{array}{l}\text { FISH/ PCR } \\
\text { BCR/ABL } \\
\text { Blood or } \\
\text { Bone } \\
\text { Marrow }\end{array}$ & $\begin{array}{l}\text { Philadelphia } \\
\text { Chromosome } \\
\text { Positive }\end{array}$ & $\begin{array}{l}\text { Negative for } \\
\text { BCR/ABL } \\
\text { translocation } \\
\text { by RT-PCR (BM) }\end{array}$ & $\begin{array}{l}\text { Negative for } \\
\text { BCR/ABL } \\
\text { translocation } \\
\text { (PB) }\end{array}$ & $\begin{array}{l}\text { Positive } \\
\text { minor } \\
\text { breakpoint } \\
.014 \%\end{array}$ & $\begin{array}{l}\text { FISH positive BCR/ABL; } \\
\text { RT PCR positive for the } \\
\text { minor breakpoint region } \\
39.22 \%\end{array}$ & $\begin{array}{l}4.4 \text { percent } \\
\text { by FISH } \\
\text { analysis }\end{array}$ & $\begin{array}{l}\text { Negative for } \\
\text { BCR/ABL } \\
\text { translocation } \\
\text { by RT-PCR }\end{array}$ & $\begin{array}{l}\text { Negative for } \\
\text { BCR/ABL } \\
\text { translocation }\end{array}$ \\
\hline $\begin{array}{l}\text { TKI } \\
\text { treatment }\end{array}$ & N/A & None & $\begin{array}{l}\text { Gleevec } \\
100 \mathrm{mg}^{*}\end{array}$ & $\begin{array}{l}\text { Gleevec } \\
100 \text { mg* }^{*}\end{array}$ & $\begin{array}{l}\text { Nilotinib ( } 400 \text { mg po } \\
\text { bid started) }\end{array}$ & $\begin{array}{l}\text { Nilotinib } \\
(400 \mathrm{mg} \text { po } \\
\text { bid) }\end{array}$ & $\begin{array}{l}\text { Nilotinib } \\
800 \mathrm{mg} \\
(400 \mathrm{mg} \text { po } \\
\text { bid) }\end{array}$ & $\begin{array}{l}\text { Nilotinib } \\
\text { (400 mg po } \\
\text { bid) }\end{array}$ \\
\hline GVHD & N/A & skin and gut & skin & skin & skin & $\begin{array}{l}\text { skin, eyes, } \\
\text { mouth, and } \\
\text { gut }\end{array}$ & $\begin{array}{l}\text { skin, eyes, } \\
\text { mouth, and } \\
\text { gut }\end{array}$ & $\begin{array}{l}\text { skin, eyes, } \\
\text { mouth, and } \\
\text { gut }\end{array}$ \\
\hline ECP & N/A & None & None & None & None & None & None & ECP ** \\
\hline \multirow[t]{2}{*}{ IST } & N/A & $\begin{array}{l}\text { Cyclosporine } \\
\text { and Prednisone }\end{array}$ & $\begin{array}{l}\text { Cyclosporine } \\
\text { and } \\
\text { Prednisone }\end{array}$ & Weaned & Discontinued & $\begin{array}{l}\text { Cyclosporine: } \\
125 \text { mg p.o.b. } \\
\text { i.d. }\end{array}$ & $\begin{array}{l}\text { Cyclosporine: } \\
150 \text { mg p.o.b. } \\
\text { i.d. }\end{array}$ & $\begin{array}{l}\text { CellCept: } \\
1000 \text { mg p.o. } \\
\text { b.i.d. }\end{array}$ \\
\hline & & & & & & $\begin{array}{l}\text { Prednisone: } \\
25 \text { mg daily }\end{array}$ & & $\begin{array}{l}\text { Prednisone: } \\
10 \mathrm{mg}\end{array}$ \\
\hline
\end{tabular}

\footnotetext{
* The patient was unable to tolerate a higher dose of Gleevec due to low platelet counts. $B M$ bone marrow.

$P B$ peripheral blood.

FISH fluorescent in situ hybridization.

$P C R$ polymerase chain reaction; $R T-P C R$ reverse transcription polymerase chain reaction.

$T K I$ tyrosine-kinase inhibitor.

GVHD graft-versus-host disease.

ECP extracorporeal photopheresis.

IST immunosuppressive therapy.
}

**ECP treatments- Treatments were scheduled bi weekly for eight weeks, then once every two weeks for eight weeks, then once a month.

evidence of acute lymphoblastic leukemia. Since October 2011, she has been maintained on CellCept, low dose prednisone, and intermittent ECP treatments for her GVHD. Her GVHD is currently stable with skin thickening, sclerodermatous of her legs and upper thighs, eye dryness, and dry mouth (Figure 1). Nilotinib dose is maintained at $800 \mathrm{mg} /$ day and no toxicities were noted requiring dose adjustment or modification. Also, she is currently stable from the leukemia standpoint, with her last biopsy being negative for residual disease, and chimerism studies showed $100 \%$ donor cells. Also, her blood counts have maintained a normal range

\section{Discussion and Conclusion}

With the advent of tyrosine kinase inhibitors (TKI), the addition of imatinib to standard therapy has significantly improved outcomes in Ph + ALL $[2,8]$. However, the use of single agent imatinib has produced temporary response, requiring combination therapies including allogeneic transplantation [9]. In those patients resistant to imatinib, second generation TKIs, such as dasatinib and nilotinib are showing promise in clinical trials $[10,11]$. We report a combination treatment of single agent nilotinib for relapsed Ph + ALL along with immunosuppressive therapy for GVHD with ECP after related allogeneic stem cell transplantation. Our patient was originally treated with a combination regimen of Hyper-CVAD therapy with concomitant imatinib. After allogeneic transplant imatinib was reinstituted albeit at a lower dose due to thrombocytopenia. Since our patient was already on imatinib and had relapsed, we chose to use nilotinib due to the above-mentioned increased potency of nilotinib and potential to overcome imatinib resistance.

Unlike previous reports, our patient did not receive additional chemotherapy and/or donor lymphocyte infusions after relapse and went into molecular remission on 


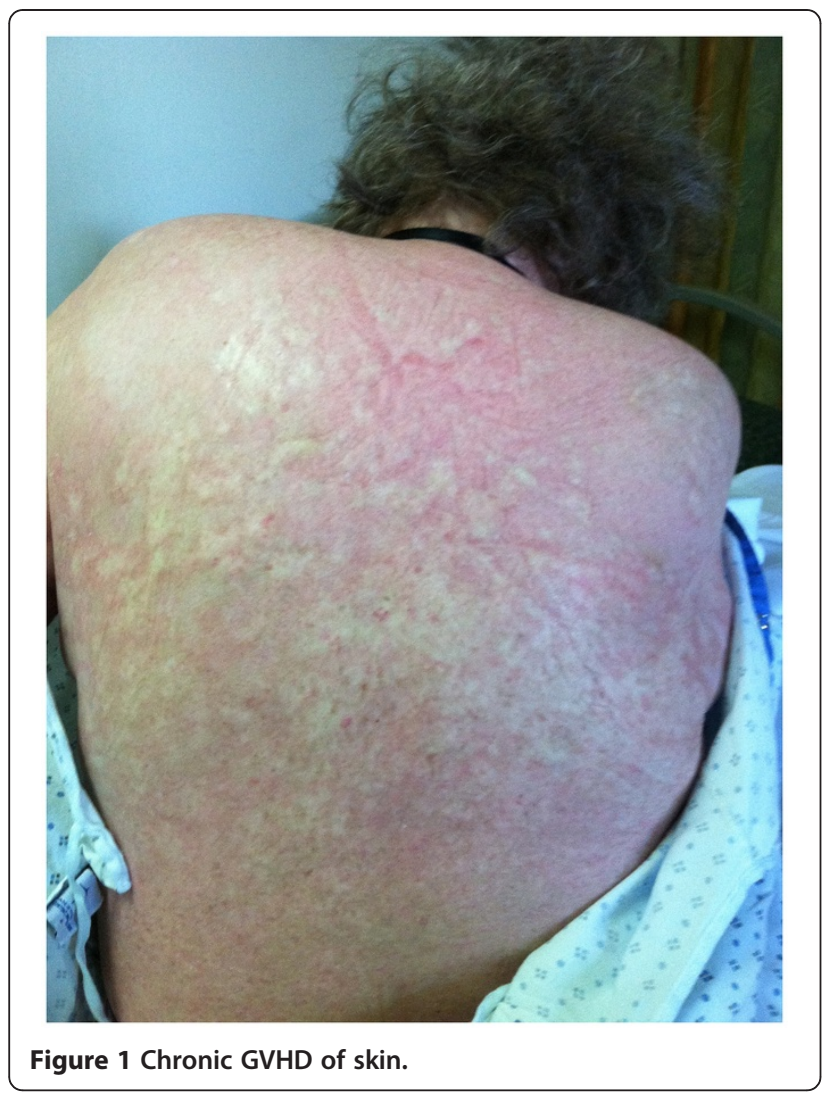

single agent nilotinib, despite $70 \%$ blasts in a hypercellular marrow $[12,13]$. One month after starting nilotinib she reverted back to $100 \%$ donor reconstitution, without additional stem cells or lymphocytes. However, this led to progression of her graft-versus-host disease. This had chronic features and the patient was steroid intolerant, due to steroid myopathy and weakness. Therefore, ECP was considered a suitable choice, especially considering her sclerodermatous changes. There is promising data about using ECP in steroid resistant/intolerant GVHD [14-16]. We were concerned about this additional immunosuppression to treat her GVHD, since this may abrogate her GVL effect. However, despite the use of corticosteroids, cyclosporine, CellCept, and ECP the patient remains in molecular remission with single agent nilotinib.

ECP is currently FDA approved for the treatment of $\mathrm{Cu}$ taneous T-Cell lymphoma (CTCL) and is a well-known treatment option for steroid-refractory chronic graft versus host disease [15-17]. The mechanism of action is not well studied. However, recent data suggests that it is possible to reduce GVHD without generalized immunosuppression [18]. ECP can affect alloreactive T-Cell activity, dendritic cells, and monocytes [19]. A recent murine study demonstrated that ECP attenuates GVHD but preserves dendritic cell vaccination response [20]. Overall these studies suggest that unlike conventional immunosuppression, ECP may selectively target the immune system and separate GVHD from GVL. Our patient could not tolerate higher doses of conventional immunosuppression due to steroid myopathy and nephrotoxicity from cyclosporine. However, her GVHD improved on ECP, and she was able to continue nilotinib to maintain remission.

In conclusion, molecular remission and graft-versusleukemia effect in Ph + ALL is sustained with the use of nilotinib as a single agent without additional chemotherapy or DLI.

\section{Consent}

Institutional review board informed consent was obtained from the patient for collection of data and for research purposes.

\section{Competing interests}

Authors state that they have no competing interests.

\section{Author's contributions}

PF and VR collected and reviewed data to compile into the paper. DW provided evidence and supporting data. All the authors reviewed and approved the final version of the report.

Received: 20 June 2012 Accepted: 15 September 2012

Published: 17 September 2012

\section{References}

1. Moorman A, Harrison C, Buck G, et al: Karyotype is an independent prognostic factor in adult acute lymphoblastic leukemia (ALL): analysis of cytogenetic data from patients treated on the medical research council (mrc) ukallxii/eastern cooperative oncology group (ecog) 2993 trial. Blood 2007, 109(8):3189-3197.

2. Hunger SP: Tyrosine kinase inhibitor use in pediatric Philadelphia chromosome-positive acute lymphoblastic anemia. Hematology Am Soc Hematol Educ Program 2011, 2011:361-365.

3. Wassmann B, Pfeifer $\mathrm{H}$, Goekbuget $\mathrm{N}$, et al: Alternating versus concurrent schedules on imatinib and chemotherapy as front-line therapy for philadelphia-positive acute lymphoblastic leukemia (ph all). Blood 2006, 108:1469-1477.

4. Ottmann O, Dombret $\mathrm{H}$, Martinelli $\mathrm{G}$, et al: Dasatinib induces rapid hematologic and cytogenetic responses in adult patients with Philadelphia chromosome positive acute lymphoblastic leukemia with resistance or intolerance to imatinib: interim results of a phase 2 study. Blood 2007, 110:2309-2315.

5. Weisberg E, Manley P, Breitenstein W, et al: Characterization of amn107, a selective inhibitor of native and mutant bcr-ab. Cancer Cell 2005, 7:129-141.

6. Ottmann OG, Pfeifer H: Management of Philadelphia chromosomepositive acute lymphoblastic leukemia (ph all). ASH Education Book 2009, 2009(1):371-381.

7. Kantarjian $H$, Giles F, Wunderle $L$, et al: Nilotinib in imatinib-resistant CML and Philadelphia chromosomepositive ALL. N Engl J Med 2006, 354:2542-2551.

8. Lee HJ, Thompson JE, Wang ES, et al: Philadelphia chromosome-positive acute lymphoblastic leukemia: current treatment and future perspectives. Cancer 2011, 117(8):1583-1594. doi:10.1002/cncr.25690.

9. Kebriaei P, Saliba R, Rondon G, et al: Long-term follow-up of allogeneic hematopoietic stem cell transplantation for patients with Philadelphia chromosome-positive acute lymphoblastic leukemia: Impact of tyrosine kinase inhibitors on treatment outcomes. Biol Blood Marrow Transplant 2012, 18(4):584-592.

10. Stock W, Prestidge T, Camitta B: Current treatment options for adults patients with Philadelphia chromosome-positive acute lymphoblastic leukemia. Leuk Lymphoma 2010, 51(2):188-198. 
11. Ravandi F: Managing Philadelphia chromosome-positive acute lymphoblastic leukemia: role of tyrosine kinase inhibitors. Clin Lymphoma Myeloma Leuk 2011, 3(6):731-742.

12. Merante SP, Colombo AA, Calatroni S, et al: Nilotinib restores long-term full-donor chimerism in ph-positive acute lymphoblastic leukemia relapsed after allogeneic transplantation. Bone Marrow Transplantation 2009, 44:263-264. doi:10.1038/bmt.2009.6.

13. Tiribelli M, Spetotto A, Candoni A, et al: Nilotinib and donor lymphocyte infusion in the treatment of Philadelphia-positive acute lymphoblastic leukemia (ph all) relapsing after allogeneic stem cell transplantation and resistant to imatinib. Leuk Res 2009, 33(1):174-177.

14. Kang BW, Moon JH, Chae YS, et al: Pre-emptive treatment with nilotinib after second allogeneic transplantation in a Philadelphia chromosomepositive acute lymphoblastic leukemia patient with high risk of relapse. Acta Haematol 2010, 123:242-247.

15. Greinix $H$, van Besien $K$, Elmaagacli A: Progressive improvement in cutaneous and extracutaneous chronic graft-versus-host disease after a 24 week course of extracorporeal photophoresis- results of a crossover randomized study. Biology of Blood and Marrow Transplantation 2011, 17(12):1775-1782.

16. Flowers M, Apperley J, van Besien $\mathrm{K}$, et al: A multicenter prospective phase 2 randomized study of extracorporeal photopheresis for treatment of chronic graft-versus-host disease. Blood 2008, 112(7):2667-2774.

17. Chiesa-Fuxench Z, Gonzalez-Chavez J: Extracorporeal photopheresis: a review on the immunological aspects and clinical applications. PR Health Sci J 2010, 29(4):337-347.

18. Marshall S: Technology insight: Ecp for the treatment of gvhd-can we offer selective immune control without generalized immunosuppression? Nat Clin Pract Oncol 2006, 3(6):302-314.

19. Goussetis E, Varela I, Tsirigotis P: Update on the mechanism of action and on clinical efficacy of extracorporeal photopheresis in the treatment of acute and chronic graft versus host disease in children. Transfus Apher Sci 2012, 46(2):203-209.

20. Capitini C, Davis J, Larabee S: Update on the mechanism of action and on clinical efficacy of extracorporeal photopheresis in the treatment of acute and chronic graft versus host disease in children. Biol Blood Marrow Transplant 2011, 17(6):790-799.

doi:10.1186/2162-3619-1-29

Cite this article as: Farnsworth et al:: Persistent complete molecular remission after nilotinib and graft-versus-leukemia effect in an acute lymphoblastic leukemia patient with cytogenetic relapse after allogeneic stem cell transplantation. Experimental Hematology \& Oncology 2012 1:29.

\section{Submit your next manuscript to BioMed Central and take full advantage of:}

- Convenient online submission

- Thorough peer review

- No space constraints or color figure charges

- Immediate publication on acceptance

- Inclusion in PubMed, CAS, Scopus and Google Scholar

- Research which is freely available for redistribution 